\title{
A gravitational model extended by institutional and cultural factors for Colombian foreign trade
}

\author{
Vivian Katherine Suárez $^{\text {a,b }}$, Jairo R. Montoya-Torres ${ }^{a^{*}}$ and Juan Pedro Sepúlveda-Rojas ${ }^{c}$
}

${ }^{a}$ Grupo de investigación en Sistemas Logísticos, Facultad de Ingeniería, Universidad de La Sabana, Km 7 autopista norte de Bogotá, D.C., Chía (Cundinamarca), Colombia

${ }^{b}$ Departamento de Administración y Organizaciones, Facultad de Ciencias de la Administración, Universidad del Valle, Calle 4B No 3600 Sede San Fernando, Edificio 124, Cali, Valle del Cauca, Colombia

${ }^{c}$ Departamento de Ingenieria Industrial, Universidad de Santiago de Chile, Av. Ecuador 3769, Santiago, Chile

C H R O N I C L E

\section{Article history:}

Received: March 31, 2021

Received in revised format: April 272021

Accepted: June 10, 2021

Available online:

June 11, 2021

Keywords:

Trade flows

Gravity equations

Cultural distance

Institutional modernity

Panel data

Colombia

\section{A B S T R A C T}

Gravitational models are currently a commonly used methodology to analyze the behavior of countries' trade flows. These studies typically seek to measure the impact of distance and the size of economies as factors that increase or decrease the propensity to trade between countries. Instead of using the traditional model, this paper introduces two distance variables which are built as modernity factors of culture and productive and institutional apparatus that give some evidence the importance of the economic and institutional stability of the countries to favor trade flows. The new model is tested using historical data of Colombia foreign trade between 1995 and 2015 (which is the most updated year publicly available).

\section{Introduction}

Newton's law relates the attraction or gravity between two objects to the size of their mass and the distance between them. When applied to business relationships, a Gravitational Model applies an analogous concept in which the size of the economy is measured by the Gross Domestic Product (GDP) as an approximation to the "mass". Traditional Gravitational Models in international trade consider geographical distance as a measure of attraction between countries. In this paper however we propose to extend the distance / attraction concept by extrapolating the analogy of the typically economic variables to the qualitative variables of culture and institutions. The proposed model is estimated with the classical variables of the gravitational models: GDP, population and Euclidean distance, but variables of cultural distance, geopolitics and modernity of the productive and institutional apparatus are included. This work is novel in that it is the first time that an extended gravity model is estimated (Kreinovich \& Sriboonchitta, 2018). To validate the model and statements, an application to the Colombian international trade flows is considered in which imports and exports from the period 1995-2015 are collected and a data panel analyzed by five-year periods. The main hypothesis of this work is that the impact of the cultural and modernity distances of the productive and institutional apparatus is a factor of stimulus in the commercial relations of Colombia. The data panel for Colombia's commercial exchanges is constructed with a group of 21 countries that represent approximately $75 \%$ of Colombia's total trade according to its main origins and destinations. As before noted, the constructed model is called expanded by the inclusion of cultural, institutional, geopolitical and modern variables of the productive apparatus. As a methodological strategy

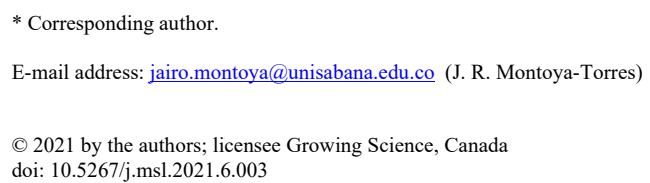


for its inclusion, two synthetic factorial variables of distance were constructed: 1. Cultural and geopolitical distance, and 2. Modernity of the productive and institutional apparatus.

This paper is organized as follows. Firstly, the problem approach is addressed. Then, the literature review is presented, followed by the detailed description of the econometric approach, the estimation methodology and the estimates. The paper ends by presenting some conclusions and opportunities for further research.

\section{Problem statement}

The process of economic integration has been strong in the world in the last fifty years. Since the post-war era, enormous efforts have appeared worldwide to establish multilateral agreements to facilitate trade and to regulate trade policy issues, such as the establishment of General Agreements Tariffs and Trade (GATT) in 1947 (WTO, 2018). In the case of Colombia, the processes of trade liberalization were strengthened from 1990 onwards as part of a trade liberalization strategy focused on strategic potential partners. After the economic opening process in 1990, Colombia continued to promote trade ties with its neighboring countries and established new relationships - now under the rules of regional agreements - with countries that are geographically and culturally distant, thus challenging the classical trade paradigm (Daniels, Radebaugn, \& Sullivan, 2010). The volumes of trade of the countries are configured as a relevant issue given the impact on economic growth and its effects on development. Therefore, the monitoring of the effects of trade policies is a topic of interest for a country such as Colombia that must validate the development strategies and policies to be followed in the determination of its public policies. Regional trade agreements have proliferated in recent decades over multilateral treaties, a situation marked by the stagnation of multilateral liberalization following the Doha Round (Kohl, 2014, Robledo et al. 2014). This round of multilateral negotiations inherits from its predecessor both a great progress and major challenges given that the agenda is pending neuralgic issues for world trade such as trade in agricultural goods, a sector historically protected by countries under the argument of guaranteeing food security. The agenda has been made more complex by the desire to achieve improvements in economic development among the developing countries. It is not entirely clear in the literature to what extent greater liberalization of trade and market opening can stimulate development in these countries without the contribution of domestic policy reforms (Arndt, 2007). What the literature has analyzed is the propensity of countries to establish ties with countries with which there is some a priori commercial affinity. From there, emerges the interest of establishing the preferential ties made concrete through the agreements, the political precedes the commercial. In this way, for the analysis of the effects of integration on the growth and development of a country, some authors have proposed Gravity Equations Models that contribute to establish the determinants of trade flows between countries as well as the effects of economic integration on trade and development (Baier, Bergstrand, \& Egger, 2007). Previous elements support the relevance of investigating the Colombian case, using Gravitational Models, the effects that the similarities or differences with partners and institutions are derived from there over the commercial flows of Colombia. This work intends to answer the following questions: What weight, in addition to the traditional factors of the Gravity Models, have the cultural, institutional, and geopolitical variables in trade flows? Are the differences between the trading partners with Colombia or rather the dynamics of each of the countries that trade with Colombia that determine the level of impact of the variables analyzed in the trade flows? How have these relationships occurred in the post-economic liberalization period in Colombia (1995-2015)?

\section{Literature review}

From the traditional understanding of trade, the distance between countries that trade generates an inverse relationship with trade flows mainly because of the costs associated with the transaction increase. This relationship is still valid today, although the concept of distance is being analyzed only in terms of geographical terms; so, the pertinence of using Gravitational Models and their current methodological variations. Studies of trade with the use of the Gravity Equations methodology were first introduced by Tinbergen (1962), through an exhaustive analysis based on the Gross Domestic Product (GDP) of the relationship of trade flows between countries. This analysis allowed us to conclude that the flows did have a direct relationship with the GDP, but that it was not proportional to the national growth. Since then, the use of Gravity Equations to study commercial exchanges between countries has become widespread. In their application, authors have sought to evaluate the impact of integration in its different forms. The literature related to economic integration has different aspects related to the impact in developed and developing countries, derived from the maturity of markets, the quality of its institutions and governance issues (Blanes \& Milgram, 2010; Dragutinović- Mitrović \& Bjelić, 2015). From another perspective, there is also an impact on integration related to the depth of integration: agreements that address only the tariff issue are less efficient than agreements that deal with more complex and complete negotiations to delimit preferential access, denominated deep integration (Ahcar \& Siroën, 2017). In face of the effects of the agreements, the phenomenon of growth and diversion of trade is present. The literature shows that countries most likely to create trade are the developed countries. This is attributed to the maturity of markets, the specialization of the economy and its strong institutions (Bary \& Setyodewanti, 2016), while the deviation is more common in countries with less developed commercial structures and with greater asymmetries of trade regimes (Dragutinović -Mitrović \& Bjelić, 2015). That is, while for developed countries trade creation is evidenced through its participation in trade blocs, in less developed countries, trade tends to deviate, especially those that lack a strong pro-trade institutionalist 
and have weak internal markets. It is in countries in which there are still strong protectionist structures where simple agreements - of tariff reduction - are effective to increase trade flows (Madhusoodanan, 2010). On the other hand, the deepest agreements are efficient in developed countries, they are the ones that benefit the most thanks to their macroeconomic stability and market maturity conditions (Martínez, Felicitas, \& Horsewood, 2009; Villar \& Esguerra, 2006).

Table 1

Synthesis of Literature that studies international trade processes using gravitational models

\begin{tabular}{|c|c|c|c|}
\hline Author(s) & Particularities & $\begin{array}{l}\text { Variation to the Gravi- } \\
\text { tational Model }\end{array}$ & Studied countries \\
\hline $\begin{array}{l}\text { Ahcar \& Siroën } \\
(2017)\end{array}$ & $\begin{array}{l}\text { The authors analyze the heterogeneity of regional agreements from the point of view of } \\
\text { the depth of the agreements. They conclude that deeper agreements increase trade more } \\
\text { than superficial agreements. They emphasize that regional agreements are developing } \\
\text { in an environment of stagnation of multilateral trade. }\end{array}$ & $\begin{array}{l}\text { Including additive in- } \\
\text { dicators as variables } \\
\text { for multiple corre- } \\
\text { spondence analysis. }\end{array}$ & 157 \\
\hline $\begin{array}{l}\text { Bary \& } \\
\text { Setyodewanti } \\
(2016)\end{array}$ & $\begin{array}{l}\text { The creation and / or diversion of trade is analyzed from the agreements. The study } \\
\text { conclude that the maturity of the internal market directly affects the creation of trade, } \\
\text { while the opposite deflects it. }\end{array}$ & Traditional & $\begin{array}{l}\text { Asia Pacific - } \\
\text { ASEAN }\end{array}$ \\
\hline $\begin{array}{l}\text { Bermeo \& Oh } \\
(2016)\end{array}$ & $\begin{array}{l}\text { For the case of Peru, findings correspond to the classic specification of the model, but } \\
\text { it is identified that, among its thirty main partners, Peru has unrealized commercial } \\
\text { potential with Argentina, the USA, Canada, Brazil, Mexico, Colombia, the United } \\
\text { Kingdom, France, Germany and Venezuela. Authors warn that Peru has not taken ad- } \\
\text { vantage of the opportunities of signed agreements. }\end{array}$ & Gravitational probit & $\begin{array}{l}\text { Peru and its trade } \\
\text { flows with } 186 \\
\text { countries }\end{array}$ \\
\hline $\begin{array}{l}\text { Dragutinović-Mi- } \\
\text { trović \& Bjelić } \\
(2015)\end{array}$ & $\begin{array}{l}\text { Special attention is paid to the intraregional trade of the Western Balkan countries and } \\
\text { the complementarity of this subregional trade integration and the process of EU acces- } \\
\text { sion. The incidence of asymmetric trade regimes in trade flows is highlighted. }\end{array}$ & $\begin{array}{l}\text { Traditional with panel } \\
\text { data }\end{array}$ & $\begin{array}{c}\text { Balkan countries } \\
\text { and the EU }\end{array}$ \\
\hline Kohl (2014) & $\begin{array}{l}\text { The authors intend to contribute to the correction of endogenous bias. They conclude } \\
\text { that the agreements promote trade by } 50 \% \text { at most and that more than half have not had } \\
\text { a discernible impact on trade and only a quarter promote trade. The characteristics of } \\
\text { the agreements, their institutional quality, design and the participation of their members } \\
\text { in the World Trade Organization are key factors. }\end{array}$ & Traditional & 153 \\
\hline Vijil (2014) & $\begin{array}{l}\text { The authors find necessary for developing countries to accompany integration agree- } \\
\text { ments with pro-trade assistance (institutions and infrastructure and development of pro- } \\
\text { ductive capacity) to maximize the benefits of integration. From a policy recommenda- } \\
\text { tion perspective, the evidence suggests that the design of commercial intervention pro- } \\
\text { jects and programs should be encouraged with a regional focus. }\end{array}$ & Gravitational & 185 \\
\hline $\begin{array}{l}\text { García, Navarro, \& } \\
\text { Gómez (2013) }\end{array}$ & $\begin{array}{l}\text { This document explores the determinants of bilateral trade flows among the Mercosur } \\
\text { countries. The results reveal that the influence of the agreement on trade has been pos- } \\
\text { itive but moderate. }\end{array}$ & $\begin{array}{l}\text { Traditional with alter- } \\
\text { native estimation } \\
\text { methods. }\end{array}$ & Mercosur \\
\hline $\begin{array}{l}\text { Arribas, Pérez, \& } \\
\text { Tortosa-Ausina } \\
\text { (2011) }\end{array}$ & $\begin{array}{l}\text { The authors seek to demonstrate that distance continues to be a relevant factor in the } \\
\text { determination of trade flows. They show that the distance between production centers } \\
\text { and places of export (which determine the internal costs of transport) affect trade flows } \\
\text { and that the degree of openness of the economy and its level of specialization also has } \\
\text { a direct relationship }\end{array}$ & $\begin{array}{l}\text { Traditional model } \\
\text { compared with a } \\
\text { model with using cor- } \\
\text { rected distance. }\end{array}$ & 59 \\
\hline $\begin{array}{l}\text { Blanes \& Milgram } \\
(2010)\end{array}$ & $\begin{array}{l}\text { The study analyzes the effects of the progressive implementation of a free trade agree- } \\
\text { ment between Morocco and the EU on the exports of the Spanish Autonomous Com- } \\
\text { munities (CC.AA.) to that country. }\end{array}$ & $\begin{array}{l}\text { Traditional (including } \\
\text { Moroccan tariffs) }\end{array}$ & Morocco and EU \\
\hline Eissa (2010) & $\begin{array}{l}\text { The EU-GCC economic integration is beneficial for both parties in terms of economic } \\
\text { development, but generates greater benefits for the EU. This is attributed to the maturity } \\
\text { of the market and the quality of its institutions. }\end{array}$ & $\begin{array}{l}\text { Traditional + qualita- } \\
\text { tive analysis approach } \\
\text { based on Governance } \\
\text { Theory }\end{array}$ & GCC - UE \\
\hline $\begin{array}{l}\text { Madhusoodanan } \\
(2010)\end{array}$ & $\begin{array}{l}\text { The region combines a low level of regional integration and the presence of relatively } \\
\text { high trade barriers. The model examines the impact of a set of macroeconomic factors } \\
\text { and other policy factors on trade flows. They identify that the export between two coun- } \\
\text { tries would increase by } 152.2 \% \text {, if there is an agreement in comparison with pairs of } \\
\text { countries without bilateral trade links. }\end{array}$ & Augmented Gravity & SAARC Region \\
\hline $\begin{array}{l}\text { Leusin \& de } \\
\text { Azevedo (2009) }\end{array}$ & $\begin{array}{l}\text { For the case of Brazil, the study concludes that despite the Brazilian bid to open in the } \\
1990 \text { 's, the cost of cross-border trade is high; intra-country trade is } 33 \text { times greater than } \\
\text { international trade. }\end{array}$ & $\begin{array}{l}\text { Gravitational with sec- } \\
\text { tional data }\end{array}$ & $\begin{array}{l}27 \text { Brazil states } \\
\text { and } 40 \text { countries }\end{array}$ \\
\hline $\begin{array}{l}\text { Martínez, Felicitas, } \\
\& \text { Horsewood } \\
(2009)\end{array}$ & $\begin{array}{l}\text { The results show that the dynamics of trade is significant and robust especially in intra- } \\
\text { and inter-block trade in developed countries (EU and NAFTA) }\end{array}$ & $\begin{array}{l}\text { Traditional - panel } \\
\text { data- endogenous fac- } \\
\text { tors - dynamic effects }\end{array}$ & $\begin{array}{l}\text { EU, Nafta, } \\
\text { Caricom, } \\
\text { MCCA, Ma- } \\
\text { ghreb and Medi- } \\
\text { terranean }\end{array}$ \\
\hline $\begin{array}{l}\text { Chen, Mai, \& Shih } \\
\text { (2007) }\end{array}$ & $\begin{array}{l}\text { The study uses trade indicators to analyze the degree of concentration of trade among } \\
\text { East Asian nations and uses the Gravity Model to identify the key factors that influence } \\
\text { bilateral trade flows between them. China is expected to play a key role in the economic } \\
\text { development of Eastern Asia. }\end{array}$ & $\begin{array}{l}\text { Traditional with con- } \\
\text { centration indicators }\end{array}$ & $\begin{array}{l}\text { Asia Pacific - } \\
\text { ASEAN }\end{array}$ \\
\hline Kandogan (2007) & $\begin{array}{l}\text { Emphasize the differences presented by studies with different specifications for the } \\
\text { same countries. In his analysis, the author evidences that the effect of international } \\
\text { blocks on trade varies according to the level of integration, the degree of implementa- } \\
\text { tion and the sector coverage of each block. }\end{array}$ & Traditional & 99 \\
\hline
\end{tabular}

At present, countries have focused their development strategies on integration processes, although this must be part of the strategy, not a substitute for it (Rodrik, 2000). However, the agreements alone do not create trade, the developed countries are 
the ones that, thanks to their macroeconomic, institutional and market conditions, are better prepared to take advantage of the potential benefits of integration (Eissa, 2010; Martínez, Felicitas, \& Horsewood, 2009). In this sense, developing countries must generate strategies that boost their markets and provide macroeconomic stability that facilitate their effective access to trade -which exceeds the exchange of primary goods- derived from agreements, which are sometimes underutilized (Bermeo $\&$ Oh, 2016). Thus, under this perspective, developing countries should complement the strategy of internationalization of their economies through the signature of integration agreements with the strengthening of their markets and economies through the establishment of trade policies with a regional focus aimed at improving, and building if necessary, pro-trade institutions and infrastructure, and guarantee macroeconomic stability and the development of the internal market and its specialization (Kohl, 2014; Vijil, 2014; Rodrik, 2000). In relation to international trade studies carried out using the methodological approach of Gravitational Equations, a synthesis is presented in Table 1, which describes the particularities of the studies, the variations applied to the gravitational model and the countries studied. As shown in the Table, there have been some attempts in the literature to improve the results of Gravitational Models by including additional variables that capture factors such as market maturity, institutional quality, depth of integration, among others. Those variations seek to understand new variables or factors that favor commercial exchanges. In a general way, they show that the pro-trade institutional modernity is necessary to favor commercial ties between countries. The studies show that given that countries are being selectively integrated through bilateral or multilateral agreements, studies that analyze trade through Gravitational Models have also had a greater impact on the analysis of the effects of integration agreements (Chen, Mai, \& Shih, 2007). In addition, there is also evidence that trade is greater among countries or blocks of countries with greater economic development (Martínez, Felicitas, $\&$ Horsewood, 2009). The conclusions of studies show how relevant is the maturity of the internal market and the quality of institutions as a determining factor of trade flows is reiterated (Eissa, 2010; Bary \& Setyodewanti, 2016; Cameron \& Trivedi, 2005). The referenced studies give evidence of the inclusion of variables of economic type to the Gravitational Models but do not account for the inclusion of variables of cultural type or reduction of multiple variables through techniques such as factorial analyses, as proposed in the current paper.

\section{Econometric approach and estimation methodology}

\subsection{An extended gravitational model}

The current Gravitational Model is a theoretical relationship widely used in economic literature to assess the impact of foreign trade between countries. It has its origin in the Gravitational Law proposed by Newton in 1687: the force of attraction between two objects $i$ and $j$ is represented as follows:

$$
F_{i j}=\frac{M_{i} M_{j}}{D_{i j}^{2}},
$$

where $F$ is the force of attraction, $M$ represents the mass of the objects, and $D$ the distance separating the objects. For its part, the analogy is established when one considers that the trade of two countries, or force of attraction, depends on the mass represented by the size of a country's economy measured by GDP and/or population and Euclidean distance, represented by the following equation:

$$
\frac{X}{M_{i j}}=\frac{G D P_{i} \times G D P_{j}}{D_{i j}^{2}},
$$

where X/M are exports or imports between countries, respectively, GDP represents the size of the countries' economy $i$ and $j$, and $D$ is the Euclidean distance between countries. Gravity models have been estimated in terms of natural logarithms and the results are interpreted as elasticities, according to the properties of the logarithms the equation is expressed as follows:

$$
\begin{aligned}
& L X_{i j}=\alpha+\ln P I B_{i}+\ln P I B_{j}-\ln D_{i j} \\
& L M_{i j}=\alpha+\ln P I B_{i}+\ln P I B_{j}-\ln D_{i j}
\end{aligned}
$$

A model composed of two independent equations is proposed for the case of Colombian commerce. On one hand, a first equation explains the imports of Colombia from each of the commercial partners analyzed, while on other hand, an equation is presented to describe the exports to the countries under study. The general Gravitational Model is split to propose an Extended Gravitational Model that considers the classic and new variables: GDP and Euclidean distance, population, average tariff, degree of openness and the distances of modernity of the productive and cultural apparatus. Using the standard data panel structure and methodology (Wooldridge, 2016), three possible models are considered as follows. Model 1 is a grouped regression model that ignores the structure of the panel and assumes that there is a common country effect on the dependent variable. In Model 2, $\alpha_{i}$ captures the fixed country effects, a fixed intercept in time for each of the countries. Finally, in Model 3 , idiosyncratic country effects are captured randomly and would enter the estimate as part of the error through a country random effect $u_{i}$, in which case the error would be composed of $e_{i t}+u_{i}$. Being a double logarithmic model, the parameters $\beta$ 's represent an elasticity of each of the dependent variables with respect to exports. It is expected a priori that, independently of whether it is a grouped regression model of fixed or random effects, the variables behave as follows: 
- $\quad \beta_{1}<0$ indicating that the higher the Average Tariff $\left(A P_{i t}\right)$, the lower the level of exports / imports from Colombia to country $i$.

- $\quad \beta_{2}>0$ indicating that the greater the degree of opening $\left(G A_{i t}\right)$, the higher the level of exports / imports from Colombia to country $i$.

- $\quad \beta_{3}>0$ indicating that the higher the logarithm of GDP ( $\left.\ln G D P P_{i t}\right)$ of the country, the greater the exports / imports from Colombia to country $i$.

- $\quad \beta_{4}>0$ indicating that the greater the logarithm of the population of the country $\left(\ln P_{i t}\right)$, the greater the exports / imports from Colombia to country $i$.

- $\quad \beta_{5}<0$ indicating that the greater the Euclidean distance $\left(\ln D E_{i t}\right)$ the lower the level of exports / imports from Colombia to country $i$.

- $\quad \beta_{6}<0$ indicating that the greater the distance in institutional and productive modernity $\left(\ln D M_{i t}\right.$ ), the lower the level of exports / imports from Colombia to country $i$.

- $\quad \beta_{7}<0$ indicating that the higher the cultural and geopolitical distance ( $\ln D C_{i t}$ ), the lower the level of exports / imports from Colombia to country $i$.

Index $i$ represents the 21 countries analyzed and $t$ is the period in time under study: 1995, 2000, 2005, 2010 and 2015.

Model 1:

$$
L E X_{i t}=\alpha+\beta_{1} A P_{i t}+\beta_{2} G A_{i t}+\beta_{3} L P I B P_{i t}+\beta_{4} L P_{i t}+\beta_{5} L D E_{i t}+\beta_{6} L D M_{i t}+\beta_{7} L D C_{i t}+e_{i t}
$$

Model 2:

$$
L E X_{i t}=\alpha_{i}+\beta_{1} A P_{i t}+\beta_{2} G A_{i t}+\beta_{3} L P I B P_{i t}+\beta_{4} L P_{i t}+\beta_{5} L D E_{i t}+\beta_{6} L D M_{i t}+\beta_{7} L D C_{i t}+e_{i t}
$$

Model 3:

$$
L E X_{i t}=\alpha_{i}+\beta_{1} A P_{i t}+\beta_{2} G A_{i t}+\beta_{3} L P I B P_{i t}+\beta_{4} L P_{i t}+\beta_{5} L D E_{i t}+\beta_{6} L D M_{i t}+\beta_{7} L D C_{i t}+e_{i t}+u_{i}
$$

With $i=1,2, \ldots, 21$ and $t=1995,2000,2005,2010,2015$.

The import model has an equivalent interpretation with the same signs expected a priori, according to the theory, for which the following models are presented:

Model 4:

$$
L I M P_{i t}=\alpha+\beta_{1} A P_{i t}+\beta_{2} G A_{i t}+\beta_{3} L P I B P_{i t}+\beta_{4} L P_{i t}+\beta_{5} L D E_{i t}+\beta_{6} L D M_{i t}+\beta_{7} L D C_{i t}+e_{i t}
$$

Model 5:

$$
L I M P_{i t}=\alpha_{i}+\beta_{1} A P_{i t}+\beta_{2} G A_{i t}+\beta_{3} L P I B P_{i t}+\beta_{4} L P_{i t}+\beta_{5} L D E_{i t}+\beta_{6} L D M_{i t}+\beta_{7} L D C_{i t}+e_{i t}
$$

Model 6:

$$
L I M P_{i t}=\alpha_{i}+\beta_{1} A P_{i t}+\beta_{2} G A_{i t}+\beta_{3} L P I B P_{i t}+\beta_{4} L P_{i t}+\beta_{5} L D E_{i t}+\beta_{6} L D M_{i t}+\beta_{7} L D C_{i t}+e_{i t}+u_{i}
$$

With $i=1,2, \ldots, 21$ and $t=1995,2000,2005,2010,2015$.

\subsection{Data}

The sources and units in which the estimated variables for Models 1 to 6 are measured are described next. The countries analyzed represent classic Colombia partners as well as emerging and potential partners. The set of 21 countries represent approximately $75 \%$ of the flows of imports and imports in the 20 years between 1995 and 2015, which are analyzed in 5 quinquennials. These countries are Germany, Argentina, Brazil, Canada, Chile, China, Ecuador, Spain, United States, India, Israel, Japan, Mexico, Panama, Peru, Republic of Korea, Republic of South Africa, Russia, Turkey, Uruguay and Venezuela. The data of imports and exports were taken from the Colombian National Department of Statistics (DANE) and are presented in Millions of American Dollars. The Gross Domestic Product (GDP) was considered at current prices in US dollars. The number of inhabitants was taken from the database of World Development Indicators of the World Bank. To compute the Euclidean distance, the geographic coordinates of the countries taken from the World Factbook of the Central Intelligence Agency (CIA) of the United States were used. The Average Tariffs were taken from the database of the World Trade Organization (WTO), the percentages correspond to the average tariffs. On the other hand, the degree of openness was calculated with data on import and export flows and GDP. Modernity gaps or distances of the productive and institutional apparatus and of geopolitics and culture were built using factor analysis to synthesize the variables. With this analysis, the variables were 
synthesized into two factors that represent a particular set of characteristics of the countries. In order to determine these factors, the model used historical cultural data such as language, the historical colonial past, religion and geopolitics, the cultural dimensions of Hofstede (2011) and variables of the Index of Economic Freedom, such as the legal system and intellectual property rights, the freedom of international trade, the degree of market opening and tariff and non-tariff barriers. Other factors evaluated were the fiscal and monetary discipline and the modernity of the economy, these two according to their dependence on the primary sector and hydrocarbons.

\subsection{Estimates}

Table 2 presents the estimates of Models 1 to 3 corresponding to exports, using the Fisher's $\mathrm{F}$ test that compares the fixed effects against a pooled model that does not know the structure of the panel. These results show evidence in favour of the fixed effects versus the pooled. So the pooled model was discarded. Then, the fixed-effect model is compared with the randomeffects model by means of the Hausman test, which rejects the equality of the model parameters. This indicates that the relevant model is the random effects model. These are results of the estimation for explanatory export models. Now, from the point of view of the interpretation of the parameters, it was confirmed that Colombian exports to each of the countries have a negative statistically significant and very small elasticity with respect to distance. This corroborates the traditional theory of Gravitational Models for Colombia. In terms of population, an increase of $1 \%$ of the population of one of the partner countries implies an almost unitary increase in exports to that country given the parameter of 0.95320 . The variable of average tariff follows the expected sign and significance of $99 \%$ that indicates that the increase of the tariff levels by $1 \%$ decreases exports by 0.047 . The GDP has a significance of $99.9 \%$, which shows that, according to the parameter, an increase of $1 \%$ generates an increase of $1.5 \%$ in export flows. The degree of openness is not significant. Regarding the constructed variables of distances, the modernity gap of the productive and institutional apparatus has significance of $95 \%$ and parameter of -1.85 , which means that an increase in institutional distance generates a decrease in exports. On the other hand, cultural distance is not significant. The $\rho$ parameter can explain that $67 \%$ of the variance of the error is due to randomness. In regards of the estimation of import models, results are presented in Table 3. When comparing the goodness of fit, the best behavior is that of the fixed effects model. In addition, the main findings show that the population is a significant parameter, as well as GDP and institutional distance. On the other hand, the average tariff and cultural distance are not, while the degree of openness, although significant, has a very small parameter. The $\rho$ coefficient for has an explanatory power of the variance of the high error with a magnitude of $97 \%$.

Table 2

Panel models for exports.

\begin{tabular}{|c|c|c|c|c|}
\hline Variable & $\mathrm{MCO}$ & MCO_D & Fixed & Random \\
\hline & Model 1 & Model 2 & Model 2 & Model 3 \\
\hline Distance & $-0.00019 * *$ & $-0.00076 * * *$ & (omitted) & $-0.00022 * *$ \\
\hline Log population & $0.72638 * *$ & $3.81431^{*}$ & $3.81431 * *$ & $0.95320 * * *$ \\
\hline Average Tariff & $-0.06311^{*}$ & -0.03765 & $-0.03765^{*}$ & $-0.04786^{* *}$ \\
\hline LGDP & $0.90148 * *$ & $1.53424 * * *$ & $1.53424 * * *$ & $1.50027 * * *$ \\
\hline Degree of opening & 0.00337 & 0.00221 & 0.00221 & 0.00559 \\
\hline log_DM & $-1.84704 *$ & $-1.96454 * *$ & $-1.96454^{*}$ & $-1.85585^{*}$ \\
\hline $\log \_\mathrm{DC}$ & 0.12738 & $1.47754^{*}$ & 1.47754 & 0.34485 \\
\hline $\mathrm{R}^{2}$ & 0.61 & 0.90 & & \\
\hline $\mathrm{R}^{2}$ Within & & & 0.7232 & 0.6910 \\
\hline $\mathrm{R}^{2}$ between & & & 0.0614 & 0.6320 \\
\hline $\mathrm{R}^{2}$ overall & & & 0.0842 & 0.6094 \\
\hline Sigma $u(\alpha)$ & & & 5.40 & 1.02 \\
\hline Sigma $e$ & & & 0.72 & 0.72 \\
\hline Rho $(\rho)$ & & & 0.98 & 0.67 \\
\hline $\operatorname{Lambda}(\lambda)$ & & & & 0.70 \\
\hline
\end{tabular}

F test: $F(20,77)=12.73$ Prob $>F=0.0000$

Test Hasman: H0:

$\mathrm{Chi}^{2}(6)=39.85$

Prob $>$ chi $2=0.0000$

Own calculations, outputs in STATA $\AA *$ Significance of $95 \%$

$* * 99 \%$ significance $* * * 99.9 \%$ significance 
Table 3

Panel models for imports.

\begin{tabular}{|c|c|c|c|c|}
\hline Variable & $\mathrm{MCO}$ & Fixed & MCO_D & Random \\
\hline Disacol & $-0.00019 * *$ & (omitted) & -0.00019 & $-0.00015^{* *}$ \\
\hline Log population & $0.72638 * *$ & $2.28081^{*}$ & $2.28081^{*}$ & $1.02304 * * *$ \\
\hline ArPro & $-0.06311^{*}$ & -0.00466 & -0.00466 & -0.00973 \\
\hline Log GDP_pc & $0.90148 * *$ & $1.21087 * * *$ & $1.21087 * * *$ & $1.32442 * * *$ \\
\hline g_ap & 0.00337 & $0.01340 * *$ & $0.01340 * * *$ & $0.01123 * * *$ \\
\hline log_DM & $-1.84704 *$ & $-2.63561 * * *$ & $-2.63561 * * *$ & $-2.40531 * * *$ \\
\hline $\log \_\mathrm{DC}$ & 0.12738 & 0.32804 & 0.32804 & 0.35709 \\
\hline $\mathrm{R}^{2}$ & 0.7260 & & 0.9433 & \\
\hline $\mathrm{R}^{2}$ within & & 0.7258 & & 0.7173 \\
\hline $\mathrm{R}^{2}$ between & & 0.2391 & & 0.7043 \\
\hline $\mathrm{R}^{2}$ overall & & 0.2591 & & 0.7057 \\
\hline Sigma $u(\alpha)$ & & 2.7348435 & & 0.97939979 \\
\hline Sigma $e$ & & 0.48376348 & & 0.48376348 \\
\hline Rho $(\rho)$ & & 0.96965965 & & 0.80387438 \\
\hline $\operatorname{Lambda}(\lambda)$ & & & & 0.78 \\
\hline
\end{tabular}

F test: $F(20,77)=18.92$ Prob $>F=0.0000$

Test Hasman: H0:

$\mathrm{Chi}^{2}(6)=4.81$

Prob $>$ chi $^{2}=0.5682$

Own calculations, outputs in STATA $\AA *$ Significance of $95 \%$

$* * 99 \%$ significance $* * * 99.9 \%$ significance

\section{Discussion and concluding remarks}

According to the estimates presented by the numerical results, it is concluded that for the export and import flows in Colombia the expected behaviour of the modelled variables is fulfilled. In the case of exports, the best fit model was the random effect panel, while the best model for imports was the fixed effects model. The Euclidean distance is significant for exports, the population is significant for both flows, as is the GDP and the distance of the modernity of the productive and institutional apparatus. Colombia establishes greater flows with countries with a lower relative distance, that is, with countries with a similar level of modernity. The cultural distance is not significant, this barrier has been overcome and it is traded indifferently with countries of great cultural distance, perhaps due to the westernization that the world has suffered at present. Tariffs are significant for exports, although to a small extent and not for imports. This can be explained by the need for the goods that enter the Colombian economy and its inelasticity. The degree of openness on their part is not significant in exports and very little significant for imports. Population, distance, and GDP per capita are the classical variables of Gravitational Models that purport to explain trade, which has been the traditional behaviour for Colombian trade. On the other hand, from the point of view of the hypothesis evaluated at a cultural level of institutional modernity and the productive apparatus, it is found that Colombia has a high dependence on the trade flows of both imports and exports related to the degree of modernization of the country of origin or destination. There is a greater propensity to do business with countries with a lower degree of modernization than the Colombian economy (i.e., less developed economies than Colombia). Model estimations show that the parameters are different for the flow of imports and exports, while in the case of exports the degree of openness of the trading partners is not important, but it does for imports: to a greater openness degree, it is more likely to generate import flows. Average tariffs behave as expected, the higher their levels, the lower the trade flows. However, the parameter tends to become insignificant in exports, while not significant in terms of imports. This can be related to the inelasticity of imported goods given the technological dependence of the developing country with the adoption of the import substitution model (Ortiz Quevedo \& Vásquez Castro, 2007).

\section{References}

Ahcar, J., \& Siroën, J. (2017). Deep integration: Considering the heterogeneity of free trade agreements. Journal of Economic Integration, 32(3), 615-659.

Arndt, S. W. (2007). Doha Development Round: Reaching Beyond Trade Liberalization. Pacific Economic Review, 12(3), 381-394. 
Arribas, I., Pérez, F., \& Tortosa-Ausina, E. (2011). A New Interpretation of the Distance Puzzle Based on Geographic Neutrality. Economic Geography, 87(3), 335-362.

Baier, S. L., Bergstrand, J. H., \& Egger, P. (2007). The New regionalism: Causes and consequences. Economie Internationale, 1(109), 9-29.

Bary, P., \& Setyodewanti, R. (2016). Variation of regional trade agreement impact across member countries: The case of Southeast Asia. Journal of Applied Economic Sciences, 6 (41), 379-384.

Bermeo, M., \& Oh, J. (2016). Patterns and potentials of Peru's international trade: A gravity approach. Regional and Sectoral Economic Studies, 16(2), 41-55.

Blanes, J. V., \& Milgram, J. (2010). Impact of trade liberalization on export of Morocco by region. Revista de Economia Aplicada, 18(52), 63-90.

Cameron, C., \& Trivedi, P. K. (2005). Microeconometrics Methods and Aplications. New York: Cambridge University Press.

Chen, C., Mai, C., \& Shih, C. (2007). China and East Asia: An Appraisal of Regional Economic Integration. Journal Eurasian Geography and Economics, 48(3), 320-340.

Comunidad Andina de Naciones (2018). Quiénes Somos: Comunidad Andina de Naciones. Obtenido de Comunidad Andina de Naciones : http://www.comunidadandina.org/Seccion.aspx?id=195\&tipo=QU\&title=resena-historica

Daniels, J., Radebaugn, L., \& Sullivan, D. (2010). Negocios Internacionales. México: Pearson Education.

Dragutinović-Mitrović, R., \& Bjelić, P. (2015). Trade regimes and bilateral trade in the EU enlargement process: Focus on the Western Balkans. Acta Oeconomica, 65(2), 249-270.

Eissa, N. (2010). GCC economic integration in the world economy and it's role in the current economic crisis. Knowledge Management and Innovation: A Business Competitive Edge Perspective (pp. 1513-1522). El Cairo: Elsevier.

García, E., Navarro, M., \& Gómez, E. (2013). The gravity model analysis: An application on MERCOSUR trade flows. Journal of Economic Policy Reform, 16(4), 336-348.

Greene, W. H. (1999). Análisis econométrico. Madrid: Pearson Education.

Kalmanovitz, S. (2015). Breve Historia Económica de Colombia. Bogota : Utadeo.

Kandogan, Y. (2007). Sensitivity of international blocs' trade effect to alternative specifications of the gravity equation. Journal of Applied Economics, 10(2), 337-360.

Kohl, T. (2014). Do we really know that trade agreements increase trade? Review of World Economics, 150(3), 443-469.

Kreinovich, V., \& Sriboonchitta, S. (2018). Quantitative Justification for the Gravity Model in Economics. Studies in Computational Intelligence, 753, 214-221.

Leusin, J. S., \& de Azevedo, A. (2009). The border effect in Brazilian regions: A gravity model approach [O efeito fronteira das regiões Brasileiras: Uma aplicação do modelo gravitacional]. Revista de Economia Contemporanea, 13(2), 229-258.

Madhusoodanan, P. (2010). An empirical examination of trade flows in the SAARC region. International Journal of Business and Globalisation, 5(3), 273-279.

Martínez, I., Felicitas, L., \& Horsewood, N. (2009). Are regional trading agreements beneficial?: Static and dynamic panel gravity models. North American Journal of Economics and Finance, 20(1), 46-65.

Ministerio de Comercio, Industria y Turismo. (23 de Mayo de 2018). Acuerdos Vigentes. Obtenido de Mincit: http://www.tlc.gov.co/publicaciones/5398/acuerdos vigentes

World Trade Organization (2018). A cerca de la OMC. Obtenido de Historia del sistema multilateral de comercio: https://www.wto.org/spanish/thewto_s/history_s/history_s.htm

Ortiz Quevedo, C. H., \& Vásquez Castro, L. M. (2007). Aprendizaje Manufacturero, Dependencia Tecnológica y Crecimiento Económico: El Caso Colombiano. Revista Sociedad y Economía, 12, 10-27.

Robledo, S., Osorio, G. A., \& López, C. (2014). Networking en pequeña empresa: una revisión bibliográfica utilizando la teoría de grafos. Revista Vínculos, 11(2), 6-16.

Rodrik, D. (2000). Cómo hacer que la apertura funcione . Bogota: Tercer Mundo Editores.

Tinbergen, J. (1962). Shaping the World Economy. New York: Twentieth Century, 27-30.

Vijil, M. (2014). Aid for trade effectiveness: Complementarities with economic integration. World Economy, 37(4), 555-566.

Villar, L., \& Esguerra, P. (2006). El Comercio Exterior Colombiano en el Siglo XX. En M. Urrutia, \& J. Robinson, Historia Económica de Colombia en el Siglo XX (págs. 1-53). Bogota: Banco de la República.

Wooldridge, J. M. (2016). Introductory Econometrics. Boston: Cengage Learning. 


\section{Appendix 1}

Trade Agreements signed by Colombia since 2000

\begin{tabular}{lc}
\hline \multicolumn{1}{c}{ Agreement } & Year signed \\
\hline Economic complementation with the Republic of Cuba & 2001 \\
Free trade agreement with El Salvador, Guatemala and Honduras & 2007 \\
Free trade agreement with Chile & 2009 \\
Free trade agreement with EFTA associated states & 2010 \\
Commercial Promotion Agreement between the Colombia and Canada & 2010 \\
Alianza Pacífico & 2012 \\
Partial Scope Agreement with the Bolivarian Republic of Venezuela & 2012 \\
Trade agreement between the European Union, Colombia and Peru & 2013 \\
Free trade agreement with Costa Rica & 2013 \\
Free trade agreement with the Republic of Korea & 2016 \\
\hline Economic complementation with agreement with Mercosur & 2017 \\
\hline
\end{tabular}

Source: own elaboration using data collected from the Ministry of Commerce, Industry and Tourism database

Appendix 2

Imports of Colombia, in millions USD

\begin{tabular}{|c|c|c|c|c|c|}
\hline Country & 1995 & 2000 & 2005 & 2010 & 2015 \\
\hline Germany & 775.977 .938 & 488.850 .215 & 773.661 .099 & 1.611 .427 .478 & 2.267 .454 .117 \\
\hline Argentina & 208.776 .693 & 147.776 .674 & 411.711 .411 & 1.509 .263 .035 & 501.487 .660 \\
\hline Brazil & 430.563 .240 & 509.664 .736 & 1.383 .387 .275 & 2.369 .636 .539 & 2.084 .310 .011 \\
\hline Canada & 496.266 .013 & 292.918 .946 & 389.315 .000 & 823.442 .190 & 877.155 .382 \\
\hline Korea, Republic of & 3.482 .117 & 3.336 .032 & 2.659 .636 & 11.936 .119 & 3.247 .249 \\
\hline Chile & 211.422 .370 & 255.590 .732 & 377.144 .145 & 736.502 .941 & 780.650 .793 \\
\hline China & 129.174 .711 & 355.825 .083 & 1.616 .821 .229 & 5.477 .436 .796 & 10.032 .488 .796 \\
\hline Ecuador & 323.819 .913 & 316.791 .160 & 529.000 .841 & 834.935 .735 & 783.082 .802 \\
\hline Spain & 344.340 .955 & 210.389 .932 & 333.314 .067 & 501.562 .372 & 915.251 .380 \\
\hline USA & 4.823 .572 .612 & 3.878 .113 .900 & 6.005 .625 .330 & 10.437 .149 .453 & 15.512 .402 .057 \\
\hline India & 41.463 .579 & 65.148 .381 & 247.930 .422 & 686.257 .020 & 1.199 .232 .253 \\
\hline Israel & 63.956 .480 & 64.151 .360 & 99.400 .935 & 268.428 .623 & 165.446 .539 \\
\hline Japan & 957.687 .302 & 542.838 .513 & 705.314 .547 & 1.156 .642 .575 & 1.227 .454 .131 \\
\hline Mexico & 516.238 .669 & 549.041 .930 & 1.757 .067 .552 & 3.856 .674 .125 & 3.852 .939 .651 \\
\hline Panama & 20.689 .712 & 20.824 .551 & 62.525 .787 & 180.077 .797 & 93.148 .817 \\
\hline Peru & 124.055 .287 & 144.714 .620 & 350.106 .499 & 786.248 .834 & 937.225 .660 \\
\hline Russia & 44.156 .381 & 51.626 .405 & 138.845 .377 & 182.485 .060 & 403.814 .787 \\
\hline South Africa & 50.632 .562 & 29.675 .419 & 42.012 .201 & 35.511 .356 & 36.685 .062 \\
\hline Turkey & 5.602 .546 & 7.125 .426 & 19.800 .734 & 56.752 .798 & 239.943 .589 \\
\hline Uruguay & 15.582 .453 & 11.997 .019 & 27.516 .865 & 59.080 .071 & 73.919 .030 \\
\hline Venezuela & 1.311 .809 .338 & 944.948 .080 & 1.219 .123 .631 & 304.745 .741 & 292.118 .039 \\
\hline T 21-partners & 10.899 .270 .871 & 8.891 .349 .114 & 16.492 .284 .582 & 31.886 .196 .661 & 42.279.457.806 \\
\hline Total & 13.680 .511 .903 & 11.757 .003 .740 & 21.204 .163 .286 & 40.485 .555 .690 & 54.057 .599 .472 \\
\hline $\begin{array}{l}\text { Participation of } 21 \\
\text { partners }\end{array}$ & $79,7 \%$ & $75,6 \%$ & $77,8 \%$ & $78,8 \%$ & $78,2 \%$ \\
\hline
\end{tabular}

Source: own elaboration using collected data from the Colombian National Department of Statistics (DANE) 
Appendix 3

Exports of Colombia, in millions USD

\begin{tabular}{|c|c|c|c|c|c|}
\hline Country & 1995 & 2000 & 2005 & 2010 & 2015 \\
\hline Germany & 775.977 .938 & 488.850 .215 & 773.661 .099 & 1.611 .427 .478 & 2.267.454.117 \\
\hline Argentina & 208.776 .693 & 147.776 .674 & 411.711 .411 & 1.509 .263 .035 & 501.487 .660 \\
\hline Brazil & 430.563 .240 & 509.664 .736 & 1.383 .387 .275 & 2.369 .636 .539 & 2.084 .310 .011 \\
\hline Canada & 496.266 .013 & 292.918 .946 & 389.315 .000 & 823.442 .190 & 877.155 .382 \\
\hline Korea, Republic of & 3.482 .117 & 3.336 .032 & 2.659 .636 & 11.936 .119 & 3.247 .249 \\
\hline Chile & 211.422 .370 & 255.590 .732 & 377.144 .145 & 736.502 .941 & 780.650 .793 \\
\hline China & 129.174 .711 & 355.825 .083 & 1.616 .821 .229 & 5.477 .436 .796 & 10.032 .488 .796 \\
\hline Ecuador & 323.819 .913 & 316.791 .160 & 529.000 .841 & 834.935 .735 & 783.082 .802 \\
\hline Spain & 344.340 .955 & 210.389 .932 & 333.314 .067 & 501.562 .372 & 915.251 .380 \\
\hline USA & 4.823 .572 .612 & 3.878 .113 .900 & 6.005 .625 .330 & 10.437 .149 .453 & 15.512 .402 .057 \\
\hline India & 41.463 .579 & 65.148 .381 & 247.930 .422 & 686.257 .020 & 1.199 .232 .253 \\
\hline Israel & 63.956 .480 & 64.151 .360 & 99.400 .935 & 268.428 .623 & 165.446 .539 \\
\hline Japan & 957.687 .302 & 542.838 .513 & 705.314 .547 & 1.156 .642 .575 & 1.227 .454 .131 \\
\hline Mexico & 516.238 .669 & 549.041 .930 & 1.757 .067 .552 & 3.856 .674 .125 & 3.852 .939 .651 \\
\hline Panama & 20.689 .712 & 20.824 .551 & 62.525 .787 & 180.077 .797 & 93.148 .817 \\
\hline Peru & 124.055 .287 & 144.714 .620 & 350.106 .499 & 786.248 .834 & 937.225 .660 \\
\hline Russia & 44.156 .381 & 51.626 .405 & 138.845 .377 & 182.485 .060 & 403.814 .787 \\
\hline South Africa & 50.632 .562 & 29.675 .419 & 42.012 .201 & 35.511 .356 & 36.685 .062 \\
\hline Turkey & 5.602 .546 & 7.125 .426 & 19.800 .734 & 56.752 .798 & 239.943 .589 \\
\hline Uruguay & 15.582 .453 & 11.997 .019 & 27.516 .865 & 59.080 .071 & 73.919 .030 \\
\hline Venezuela & 1.311 .809 .338 & 944.948 .080 & 1.219 .123 .631 & 304.745 .741 & 292.118 .039 \\
\hline T 21-partners & 10.899 .270 .871 & 8.891 .349 .114 & 16.492 .284 .582 & 31.886 .196 .661 & 42.279 .457 .806 \\
\hline Total & 13.680 .511 .903 & 11.757 .003 .740 & 21.204 .163 .286 & 40.485 .555 .690 & 54.057 .599 .472 \\
\hline Participation of 21 partners & $79,7 \%$ & $75,6 \%$ & $77,8 \%$ & $78,8 \%$ & $78,2 \%$ \\
\hline
\end{tabular}

Source: own elaboration using collected data from the Colombian National Department of Statistics (DANE)

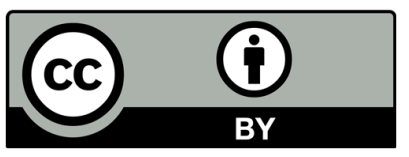

(C) 2021 by the authors; licensee Growing Science, Canada. This is an open access article distributed under the terms and conditions of the Creative Commons Attribution (CC-BY) license (http://creativecommons.org/licenses/by/4.0/). 